\title{
Rhetorical Invention
}

\section{"The Narrative You Anticipate You May Produce"}

Thomas Swiss and Seb Chevrel

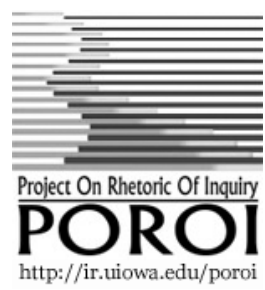

Poroi, 2, 2, November, 2003

Please see supplementary file at

http:/ / ir.uiowa.edu/cgi/ viewcontent.cogi?filename $=0 \& a r t i c l e=1046 \&$ context= poroi\&type=additional 